OPEN ACCESS

Citation: DilekAkyil (2021) Mutagenicand cytotoxic activity of insecticide Napoleon 4EC in Allium cepa and Ames test. Caryologia 74(2): 11-19. doi: 10.36253/ caryologia-1013

Received: July 06, 2020

Accepted: July 20, 2021

Published: October 08, 2021

Copyright: (c) 2021 Dilek Akyil. This is an open access, peer-reviewed article published by Firenze University Press (http://www.fupress.com/caryologia) and distributed under the terms of the Creative Commons Attribution License, which permits unrestricted use, distribution, and reproduction in any medium, provided the original author and source are credited.

Data Availability Statement: All relevant data are within the paper and its Supporting Information files.

Competing Interests: The Author(s) declare(s) no conflict of interest.

\section{Mutagenic and cytotoxic activity of insecticide Napoleon 4EC in Allium cepa and Ames test}

\author{
Dilek Akyil \\ Department of Molecular Biology and Genetic, Faculty of Arts and Sciences, Afyon \\ Kocatepe University, Afyonkarahisar/Turkey \\ E-mail: dilekakyil9@gmail.com
}

\begin{abstract}
The objective of this study was to explore the mutagenic and cytotoxic effects of Napoleon 4EC pesticide used in Turkey to control insect pest by using two standard assays. The Allium cepa test was used for determined the cytotoxic effects of this pesticide. For this test, onion seeds were exposed to Napoleon 4EC $(100,200$, and 400 ppm) for 24, 48, and 72 hours. For each test group root tip cells were stained with Feulgen and five slides were prepared for each concentration and counted microscopically. The concentrations Napoleon 4EC was compared with the value for the negative control using Dunnet-t test, 2 sided. The results indicated that mitotic index was clearly decreased with increasing the concentration of Napoleon 4EC in each treatment group as compared to the controls. The percentage of mitotic phases has been markedly impacted. Five different doses of the pesticide (50, 100, 200, 400, $800 \mu \mathrm{g} /$ plate) were examined with Ames test using Salmonella typhimurium strains TA98 and TA100 with and without S9 metabolic activation for mutagenic activity. Ames test results showed a dose dependent effect, but not twice the negative control for S. typhimurium TA98 and TA100, with or without S9 mix except $800 \mu \mathrm{g} /$ plate doses. In $800 \mu \mathrm{g} /$ plate doses, colony numbers are two-fold increase according to colony number of control group. So, this places the this compound as a weak mutagen according to the parameters.
\end{abstract}

Keywords: Allium test, Ames test, cytotoxicity, mutagenicity, Napoleon 4EC.

\section{INTRODUCTION}

The identification of chemicals capable of inducing mutations has become an important procedure in safety estimation and such substances can potentially induce to fertility problems in future generations. Mutagenic materials are also capable of inducing cancer, and this problem has been increased of the importance the mutagenicity testing systems (Kumar et al. 2013). Earlier studies have showed that some pesticides are clastogenic and mutagenic in different biological test systems (Siroki et al. 2001; Celik 2003; Stivaktakis et al. 2010; Moulas et al. 2013; Aky1l et al. 2014; Aky1l and Konuk 2015; Özkara et al. 2015a). Organophosphorus pesticides (OPs) are one of the most important groups of pesticides which have been broadly used in industry, hygiene and agriculture (Bello-Ramı'rez et al. 2000; Ballesteros and Par- 
rado 2004; Wu et al. 2007). Napoleon $4 \mathrm{EC}$ is also an OPs which has an important role to control crops.

OPs are strong inhibitors of cholinesterase enzymes and they were improved to replace organohalide pesticides in the late 1950's due to relatively easier to degrade via microbial or environmental processes (Obare et al. 2010). On the other hand, these substances or their derivatives can accumulate in the living organisms and induce mutagenicity, teratogenicity, immunotoxicity and carcinogenicity.

Short-term test methods have been used for many years from past to present to identify the genotoxic activities of pesticides (Miao et al. 2017; Özkara 2017; Khallef et al. 2018; Özkara 2019; Akyıl 2019). The shortterm test systems can detect different types of genetic DNA damage: (i) gene or point mutations; (ii) primary DNA damage and repair; (iii) chromosomal alterations.

One of these test systems is the Ames test which is used to evaluate the mutagenic activity of chemicals; it is a short-term bacterial reverse mutation assay (Mortelmans and Zeiger 2000; Liman et al. 2010; Arriaga-Alba et al. 2013; Escobar et al. 2013). The other test system is the Allium test which is one of the well-known and reliable test systems to determine the toxicity in the laboratories (Konuk et al. 2007; Liman et al. 2010; Özkara et al. 2015; Bonciu et al. 2018). To analyze the effects of different substances, higher plants (Vicia faba, Tradescantia paludosa, Pisum sativum, Hordeum vulgare, Crepis capillaris and Allium cepa, etc.) have proven to be useful when used as bioindicators (Enan 2009; Siddiqui and AlRumman 2020). However, Allium cepa has as an advantage due to its large chromosomes, easily observed with a light microscope; also in relation to the features that may reveal an effect even at relatively low level of interaction of the tested substance with the genetic material, besides its long history of use as cytotoxicological test. As it is an in vivo test, the data can be used for assessment of genotoxicity on plants and even for eukaryotes in general, including humans (Bonciu et al. 2018).

The use of insecticides has become increasingly widespread throughout the world so additional studies are necessary to determinate the potential toxic risk of insecticides on non-target organisms through bacterial mutational/ames test and Allium test, a plant assay (Yaduvanshi et al. 2012). To our knowledge, there is no study on the cytotoxicity and mutagenicity of Napoleon $4 \mathrm{EC}$ except in the present paper. The aim of this experiment was to evaluate both the mutagenic and cytotoxic effects of different doses of Napoleon 4EC by the bacterial reverse mutation assay in S. typhimurium TA98 and TA100 strains with or without S9 mix and Allium cepa test, respectively.

\section{MATERIALS AND METHODS}

\section{Chemicals and test strains}

The LT-2 TA98 and TA100 histidine demanding auxotrophs of $S$. typhimurium were kindly obtained from Prof. B.N. Ames (University of California, Berkeley). These strains were incubated for $16 \mathrm{~h}$ in liquid nutrient broth and kept at $-80^{\circ} \mathrm{C}$. Their genetic markers and other properties, such as the numbers of spontaneous revertants and responses to positive controls, were controlled as described by Maron and Ames (1983). The test substance Napoleon 4EC was purchased from a local market in Afyonkarahisar/Turkey and dissolved in sterille distilled water. Allium cepa onion bulbs, $25-30 \mathrm{~mm}$ diameter, were obtained from a local market without any treatments. The other chemicals were obtained from Merck and Riedel.

\section{Ames plate incorporation test}

The mutagenicity of the Napoleon 4EC was determined using the standard plate incorporation assay. Salmonella typhimurium strains TA98 and TA100 were used with or without $S 9$ mix in this test (Maron and Ames 1983). The tester strains were tested for the presence of the strain-specific markers as described by Maron and Ames (1983). Before the experiment, determination of the cytotoxic doses of the substance to be used during the experiment is carried out as a preliminary step. Cytotoxic doses of Napoleon 4EC (10.000, $1.000,100,10,1$ and $0.1 \mu \mathrm{g} /$ plate) were determined by the method of Dean et al. (1985). The strains were selected according to the strategies of Mortelmans and Zeiger (2000). The stock solutions of the test materials were dissolved in sterile distilled water and stored at $4^{\circ} \mathrm{C}$. The S. typhimurium strains were incubated in nutrient broth at $37^{\circ} \mathrm{C}$ for $16 \mathrm{~h}$ with shaking. A specific positive control was always used to test the experimental defect, if any, for each tester strain. Positive controls were 4-nitro-o-phenylenediamine (NPD) for TA98 and sodium azide (SA) for TA100, applied without metabolic activation, and 2-aminofluorene (AF) for TA98 and 2-aminoanthracene (2AA) for TA100 used with metabolic activation.

\section{Determination of cytotoxic doses}

For the test of cytotoxic doses were prepared by adding $0.1 \mathrm{ml}$ of the test suspension for each concentration and $0.1 \mathrm{ml}$ bacterial suspension of TA100 from an over- 
night culture to $2 \mathrm{ml}$ top agar which kept in $45^{\circ} \mathrm{C}$ water bath. The mixture was shaken for $3 \mathrm{~s}$ with a vortex mixer, and added into the nutrient agar. All test plates were incubated for $24 \mathrm{~h}$ at $37^{\circ} \mathrm{C}$ and then the revertant colonies were counted for each plate and determinated toxic and non-toxic doses which used in the experiment.

For the test of without S9 mix were prepared by adding $0.1 \mathrm{ml}$ of the test suspension for each concentration, $0.1 \mathrm{ml}$ bacterial suspension from an overnight culture, and $0.5 \mathrm{ml}$ phosphate buffer to $2 \mathrm{ml}$ top agar which kept in $45^{\circ} \mathrm{C}$ water bath. The mixture was shaken for $3 \mathrm{~s}$ with a vortex mixer, and added into the minimal agar. For the test plates with $\mathrm{S} 9 \mathrm{mix}$ were prepared by adding $0.5 \mathrm{ml}$ of $\mathrm{S} 9 \mathrm{mix}$ instead of the phosphate buffer. All test plates were incubated for $72 \mathrm{~h}$ at $37^{\circ} \mathrm{C}$ and then the revertant colonies were counted for each plate. Samples were evaluated on triplicate plates in two independent parallel experiments and all results of the experiment were analysed by the statistical analysis.

\section{Allium test}

The root inhibition test procedure was performed as described by Fiskesjo (1985). Preliminary experiments were conducted to determine the concentrations of each pesticide to be used in the actual cytotoxicity experiments. The pesticides were dissolved in distilled water. Outer scales of the bulbs and the dry bottom plates were removed without damage the root primordia. The onions were germinated in freshly distilled water for the first $24 \mathrm{~h}$ and then exposed for $96 \mathrm{~h}$ to the different doses of Napoleon 4EC $(25,50,100,200$ and $400 \mathrm{ppm}$, respectively). The roots from each group including control group were cut off on the fifth day and length of each root was measured in order to determine the $\mathrm{EC}_{50}$ values. $\mathrm{EC}_{50}$ value was determined as the concentration which retards the growth of root $50 \%$ less when compared with the control group.

\section{Root Growth Inhibition Test (EC $C_{50}$ determination)}

The onions were grown in freshly made distilled water for $24 \mathrm{~h}$ and then exposed for four days to the control group and other concentrations of extracts. In order to determine efficient concentration $\left(\mathrm{EC}_{50}\right)$ values, ten roots from each onion were cut off at the end of the treatment period, and the root's length was measured. The concentration that decreased root growth about $50 \%$ when compared to the negative control group (distilled water), was accepted as $\mathrm{EC}_{50}$ value. To determine the possible toxic effects on roots, $\mathrm{EC}_{50} / 2, \mathrm{EC}_{50}$ and $\mathrm{EC}_{50} \times 2$ concentrations of root were used in Allium mitotic index test.

The $\mathrm{EC}_{50}$ value was approximately $200 \mathrm{ppm}$ for Napoleon 4EC. In order to show possible concentration-dependent effects of this pesticide, the root tips were treated with $100 \mathrm{ppm}\left(\mathrm{EC}_{50} / 2\right), 200 \mathrm{ppm}\left(\mathrm{EC}_{50}\right)$ and $400 \mathrm{ppm}\left(\mathrm{EC}_{50} \mathrm{x} 2\right)$ concentrations of Napoleon $4 \mathrm{EC}$ and all application groups were performed 24, 48 and $72 \mathrm{~h}$ treatment periods. After treatment, the roots were washed in distilled water and fixed in 3:1 ethanol:glacial acetic acid for $24 \mathrm{~h}$ and then roots were taken in $70 \%$ alcohol and stored $+4^{\circ} \mathrm{C}$. Feulgen was used for staining root tip cells. Slides were randomly coded and scored blindly. For mitotic index (MI), the different stages of mitosis were counted in a total of 5000-6000 cells (1000 cells/slide) per concentration, and expressed as a percentage.

\section{Statistical Analysis}

Root length and MI datas were given as percentages. The levels of difference in treatment groups were analyzed statistically by SPSS 15.0 version for Windows. Dunnett-t test (2 sided) was used on both the Allium and Ames tests in the analyses.

\section{RESULTS}

Ames test results was carried out for mutagenicity determination of the tested material. For this test histidine mutant strains of S. typhymurium, TA98 and TA100 were used, and control group colony numbers were compared with the test material. The concentrations which caused two-fold increase in the colony number of control group were accepted as mutagenic ones. A compound is considered a weak mutagen if it produces a reproducible, dose-related increase in the number of revertant colonies in one or more strains but the number of revertants is not double the background number of colonies (Mortelmans and Zeiger 2000).

It was found that only $1000 \mu \mathrm{g} /$ plate concentration was cytotoxic against $S$. typhymurium strains among six tested concentrations for cytotoxicity tests $(1000,800$, $400,200,100,50$ and $25 \mu \mathrm{g} /$ plate). So this toxic concentration was not applied in Ames test. In Ames test positive controls were 4-nitro-o-phenylenediamine (NPD) for TA98 and sodium azide (SA) for TA100, used without metabolic activation, and 2-aminofluorene (AF) for TA98 and 2-aminoanthracene (2AA) for TA100 used with metabolic activation, while distilled water was used as a negative control group. Most of the results, whether 
Table 1. The mutagenicity assay results of Napoleon 4EC for S. tyhimurium TA98 and TA100 strains.

\begin{tabular}{|c|c|c|c|c|c|}
\hline \multirow{3}{*}{ Test Substance } & \multirow{3}{*}{$\begin{array}{l}\text { Concentration }(\mu \mathrm{g} / \\
\text { plate })\end{array}$} & \multicolumn{4}{|c|}{ No of His+ revertants/plate, mean \pm SD } \\
\hline & & \multicolumn{2}{|c|}{ TA98 } & \multicolumn{2}{|c|}{ TA100 } \\
\hline & & - S9 & $+\mathrm{S} 9$ & - S9 & $+S 9$ \\
\hline \multirow[t]{5}{*}{ Napoleon 4EC } & 800 & $70.20 \pm 4.14^{\star}$ & $83.24 \pm 6.25$ & $110.54 \pm 6.04$ & $197.54 \pm 11.58$ \\
\hline & 400 & $52.10 \pm 3.21$ & $83.40 \pm 3.46$ & $102.21 \pm 4.54$ & $168.21 \pm 6.52$ \\
\hline & 200 & $45.21 \pm 3.56$ & $76.45 \pm 4.32$ & $90.54 \pm 6.87$ & $154.31 \pm 10.25$ \\
\hline & 100 & $40.90 \pm 3.68$ & $65.20 \pm 6.25$ & $91.21 \pm 9.62$ & $142.30 \pm 11.54$ \\
\hline & 50 & $31.62 \pm 1.83$ & $46.70 \pm 5.54$ & $83.02 \pm 7.04$ & $138.12 \pm 12.26$ \\
\hline Neg. Control & 100 & $32.70 \pm 4.68$ & $45.21 \pm 2.57$ & $81.21 \pm 11.24$ & $126.32 \pm 5.83$ \\
\hline SA & 10 & & & $2824.56 \pm 68.31^{*}$ & \\
\hline $2 \mathrm{AA}$ & 5 & & & & $2468.24 \pm 70.15^{\star}$ \\
\hline $2 \mathrm{AF}$ & 200 & & $988.50 \pm 17.57^{\star}$ & & \\
\hline NPD & 200 & $1445.60 \pm 22.23^{*}$ & & & \\
\hline
\end{tabular}

${ }^{*}$ Mean statistically significant at $\mathrm{p}<0.05$ (Dunnett $\mathrm{t}$-test), SA:Sodium azide, NPD: 4-nitro-o-phenylendiamine, 2AF: 2-aminofluorene, 2AA: 2-aminoanthracene, SD: Standard deviation, Negative control: distilled water.

Table 2. Allium root growth inhibition test.

\begin{tabular}{lcc}
\hline Test Substance & Concentrations (ppm) & Mean of root length \pm SD \\
\hline Negative Control & - & $3.86 \pm 0.41$ \\
Positive Control & - & $1.12 \pm 0.14^{*}$ \\
Napoleon 4EC & 25 & $3.41 \pm 0.26^{*}$ \\
& 50 & $2.20 \pm 0.14^{*}$ \\
& 100 & $1.94 \pm 0.31^{*}$ \\
& 200 & $1.62 \pm 0.21^{\star}$ \\
& 400 & $1.27 \pm 0.14^{*}$ \\
\hline
\end{tabular}

*Significantly different from negative control $(\mathrm{p}<0.05$ Dunnet-t test, 2-sided) SD: Standart deviation.

increasing or decreasing relative to the negative control group, were not statistically significant at $\mathrm{P}<0.05$ (Dunnett-t test, 2 sided) except for in the $800 \mu \mathrm{g} /$ plate doses of the Napoleon 4EC in the TA98 without S9 mix.

Ames test results showed a dose dependent effect, but not twice the negative control for $S$. typhimurium TA98 and TA100, with or without S9 mix except $800 \mu \mathrm{g} /$ plate doses. In $800 \mu \mathrm{g} /$ plate doses, colony numbers are two-fold increase according to colony number of control group. So, this places the this compound as a weak mutagen according to the parameters. When S9 was added, revertant colony numbers in TA98 and TA100 became stronger and Ames test data's is summarized in Table 1.

Table 2 are summarized in Allium root growth test results. The effective concentration $\left(\mathrm{EC}_{50}\right)$ was determined as $200 \mathrm{ppm}$. Table 3 gives the effect of Napoleon $4 \mathrm{EC}$ on $\mathrm{MI}$ and mitotic phase in the root meristematic cells of A. cepa treated for 24,48 and $72 \mathrm{~h}$. At all concentrations treated in the incubations of root diminished MI compared to negative control at each exposure time. The highest values were showed from $24 \mathrm{~h}$ examination of $100 \mathrm{ppm}$, and the lowest one in $72 \mathrm{~h}$ application of $400 \mathrm{ppm}$ concentrations of Napoleon 4EC. The reduced of MI indicates statistically significant results $(\mathrm{p}<0.05)$ all concentrations and all treatment time. All doses of Napoleon 4EC applied in the experiment caused changes in the percentage of particular phases' distribution in comparison to the control.

\section{DISCUSSION}

While the use of pesticides are planned to eliminate pests and develop the quality and quantity of yield in agriculture, there is concern about their use because some have cytotoxic/mutagenic and carcinogenic effects and harm non-target organisms (Asita and Mokobo 2013). Earlier studies have reported that some pesticides have mutagenic and clastogenic activities in several biological test systems (Yaduvanshi et al. 2012; Topcu et al. 2013; Asita and Mokobo 2013; Özkara et al. 2015b; Karaismailoğlu 2016; Khallef et al. 2017).

The bacterial reverse mutation test uses amino-acid requiring strains of $S$. typhimurium to identify point mutations, which include substitution, deletion or addition of one or a few DNA base pairs. The cause of many human genetic diseases are originated point mutations and their occurrence in oncogenes and tumor suppressor genes of somatic cells are caused in tumor formation 
Table 3. The effects of Napoleon $4 \mathrm{EC}$ on $\mathrm{MI}$ and mitotic phases in the root cells of A. cepa.

\begin{tabular}{|c|c|c|c|c|c|c|c|}
\hline \multirow{2}{*}{$\begin{array}{l}\text { Concentration } \\
(\mathrm{ppm})\end{array}$} & \multirow{2}{*}{ Treatment Time } & \multirow{2}{*}{$\begin{array}{c}\text { Counted Cell } \\
\text { Number }\end{array}$} & \multirow{2}{*}{$\begin{array}{l}\text { Mitotic Index } \\
\quad \pm \text { SD }\end{array}$} & \multicolumn{4}{|c|}{ Mitotic Phases (\%) \pm SD } \\
\hline & & & & Prophase & Metaphase & Anaphase & Telophase \\
\hline Negative control & 24 hour & 5102 & $87.40 \pm 9.68$ & $83.21 \pm 10.66$ & $1.86 \pm 0.23$ & $1.01 \pm 0.45$ & $0.88 \pm 0.75$ \\
\hline Positive control & & 4802 & $43.36 \pm 4.76^{*}$ & $38.27 \pm 4.26^{*}$ & $0.62 \pm 0.17^{\star}$ & $0.55 \pm 0.54$ & $0.50 \pm 0.28$ \\
\hline 100 & & 4685 & $41.45 \pm 4.06^{*}$ & $41.10 \pm 2.71^{*}$ & $1.02 \pm 0.27^{\star}$ & $0.71 \pm 0.22$ & $1.05 \pm 0.46$ \\
\hline 200 & & 5002 & $38.21 \pm 4.25^{\star}$ & $38.44 \pm 4.02^{*}$ & $0.98 \pm 0.24^{*}$ & $1.00 \pm 0.53$ & $1.27 \pm 0.24$ \\
\hline 400 & & 5012 & $39.26 \pm 2.85^{\star}$ & $36.11 \pm 2.45^{\star}$ & $0.87 \pm 0.14^{*}$ & $0.45 \pm 0.12$ & $0.62 \pm 0.47$ \\
\hline Negative control & 48 hour & 5045 & $78.34 \pm 4.54$ & $75.21 \pm 6.47$ & $1.70 \pm 0.12$ & $1.34 \pm 0.42$ & $1.26 \pm 0.18$ \\
\hline Positive control & & 5065 & $38.22 \pm 3.12^{*}$ & $36.85 \pm 3.54^{*}$ & $0.60 \pm 0.19^{*}$ & $0.64 \pm 0.31^{*}$ & $0.72 \pm 0.31$ \\
\hline 100 & & 5145 & $31.54 \pm 3.65^{\star}$ & $37.62 \pm 3.53^{*}$ & $0.79 \pm 0.49^{*}$ & $0.76 \pm 0.12^{\star}$ & $1.21 \pm 0.24$ \\
\hline 200 & & 5214 & $28.42 \pm 3.06^{*}$ & $32.54 \pm 2.08^{*}$ & $0.62 \pm 0.14^{*}$ & $0.60 \pm 0.20^{*}$ & $1.02 \pm 0.23$ \\
\hline 400 & & 5162 & $23.40 \pm 1.48^{\star}$ & $30.54 \pm 2.78^{\star}$ & $0.45 \pm 0.23^{\star}$ & $0.51 \pm 0.11^{\star}$ & $0.92 \pm 0.41$ \\
\hline Negative control & 72 hour & 5252 & $65.45 \pm 2.23$ & $62.25 \pm 3.14$ & $1.54 \pm 0.41$ & $1.50 \pm 0.24$ & $0.94 \pm 0.25$ \\
\hline Positive control & & 5265 & $31.12 \pm 3.16^{*}$ & $32.02 \pm 3.69^{\star}$ & $0.42 \pm 0.24^{*}$ & $0.86 \pm 0.24^{\star}$ & $0.85 \pm 0.23$ \\
\hline 100 & & 5189 & $28.17 \pm 5.44^{\star}$ & $30.27 \pm 3.58^{*}$ & $0.65 \pm 0.19^{*}$ & $0.66 \pm 0.54^{\star}$ & $0.52 \pm 0.14$ \\
\hline 200 & & 4989 & $25.01 \pm 2.14^{\star}$ & $24.24 \pm 2.45^{\star}$ & $0.53 \pm 0.14^{*}$ & $0.62 \pm 0.27^{\star}$ & $0.54 \pm 0.47$ \\
\hline 400 & & 4980 & $18.17 \pm 2.25^{\star}$ & $17.45 \pm 2.07^{\star}$ & $0.38 \pm 0.47^{\star}$ & $0.49 \pm 0.14^{\star}$ & $0.61 \pm 0.51$ \\
\hline
\end{tabular}

* Significantly different from negative control ( $\mathrm{p}<0.05$ Dunnet-t test. 2-sided) SD: Standart deviation.

in experimental animals and humans (Malev 2012).

The Salmonella/microsome assay is broadly used for evaluating the mutagenicity of chemicals including pesticides (Yaduvanshi et al. 2012 ). In the present studies, Ames plate incorporation assay with the different concentrations of Napoleon 4EC showed a mutagenic response only TA98 tester strain. In order to characterize the possible mechanism of mutagenicity, the important bacterial strains, sensitive to different mutational events due to their specific geno-types, were used. There are much reports on the mutagenic effects of OPs determined with the Ames test (Aufderheide and Gressmann 2007; Coral et al. 2009; Wu et al. 2012; Akyıl and Konuk 2014). However, no study has yet reported on the in vitro mutagenicity of Napoleon 4EC using the Ames assay.

S. typhimurium TA98 strain is defined by the -1 frameshift deletion hisD3052, which effects the reading frame of a close by repetitive -C-G- bases and can be reverted by frameshift mutagens. TA100 contains the marker hisG46, which causes from a base-pair substitution of a leucine (GAG/CTC) by a proline (GGG/CCC): this mutation is reverted by mutagens causing base substitutions at G-C sequences (Di Sotto et al. 2008). In this context these bacterial properties, our results can be said that Udimo 75 WG mutagenicity in TA98 strain is caused by frameshift mutations and that of TA100 strain is due to base change (Di Sotto et al. 2008).

All concentrations of this pesticide were weak mutagenic in the TA98 and TA100 strains, with or without the S9 fraction except $800 \mu \mathrm{g} /$ plate doses of the Napo- leon 4EC in the TA98 without S9 mix. In $800 \mu \mathrm{g} /$ plate doses, colony numbers are two-fold increase according to colony number of control group. Exposure to the pesticide induced G-C base pair mutations (Maron and Ames, 1983) causing a frameshift reversion of the histidine-dependent tester strain (TA98) to the wild type $\left(\right.$ his $\left.^{+}\right)$. However, the addition of S9 mixture resulted in a reduction of the mutagenic effect of Napoleon 4EC but not significant according to negative control. Due to biotransformation, a compound that is active biologically can be changed to an inactive metabolite. Similarly an inactive compound can be changed to an active metabolite (Paolini and Forti 1997). In other words, the presence of an eukaryote enzyme in $\mathrm{S} 9$ fraction resulted in eliminate of the mutagenic activity of the tested substance. Therefore, it is vital to use the S9 fraction in the Ames test.

Yaduvanshi et al. (2012) reported that negative results for chlorpyrifos-an organophosphate pesticidewith all three tester strains (TA97, TA98, TA102) of Salmonella used in the presence or absence of metabolic activation. However, chlorpyrifos was toxic in TA98 tester strain at the dose of $5000 \mu \mathrm{g} /$ plate in absence of metabolic activation while reduction in toxicity was seen on addition of $S 9$ mixture. In another study, five different concentrations of the Chlorthiophos were tested by Ames test using Salmonella typhimurium strains TA97, TA98, TA100, and TA102, with and without S9 metabolic activation. No concentrations of Chlorthiophos showed mutagenic activity on the TA97, TA100, and 
TA102 strains, with and without $S 9$ fraction, but were all mutagenic to the TA98 strain without S9 (Akyll and Konuk 2014). Many researchers who have studied Ames test systems with OPs also reported mutagenic or nonmutagenic result (Aiub et al. 2002; Kumar et al. 2013; Arroyo et al. 2015; Akyil et al. 2017). Chemicals which tested with different test methods can be genotoxic or not genotoxic depending on a number of factors such as chemical structure, biological activity, the positions of the binding location and having rings in the structure (Kutlu et al. 2011). Furthermore, it might be related to differences in test conditions, such as exposure time, concentrations of substances, the dispersal of the materials in the cell and physico-chemical characteristics of the chemicals (Ema et al. 2012; Kaur et al. 2014). Therefore, it could be explained why some studies find an increase of genetic damage while in others result as negative.

It is well known that plants are direct recipients of toxins and the Allium cepa assay is one of the plant assay method used broadly to study the genotoxicity of pesticides (Fernandes et al. 2007). Also, Allium cepa showed a good correlation with the results from other established test systems using eukaryotic as well prokaryotic cells (Yildiz et al. 2009).

Mitotic index is a parameter that allows to estimate the frequency of cellular division (Marcano et al. 2004) and the reduction of mitotic activities has been used frequently to determine the cytotoxicity (Linnainmaa et al. 1978). Many investigators have reported the change mitotic index following the treatment of test organisms with pesticides (Panda and Sahu 1985; Amer and Farah 1974). In this experiment, mitotic index mostly decreased with increase Napoleon 4EC concentrations at each treatment times in comparison with control groups $(p<0.05)$. When the phase frequencies are compared with control in different treatment groups, significant outcomes were obtained statistically $(\mathrm{p}<0.05)$. The percentages of the mitotic phases were clearly influenced in totally almost all applications $(\mathrm{p}<0.05)$.

Chlorpyrifos, the active ingredient in Napoleon $4 \mathrm{EC}$, was shown to a dose-dependent increase in DNA damage in the liver and brain of rats using the single cell gel electrophoresis (or comet) assay (Mehta et al. 2008). Chlorpyrifos is known to generate oxidative stress, induce lipid peroxidation, and cause depletion of reduced glutathione (GSH), increase in oxidized glutathione (GSSG), and decrease in the ratio of GSH/GSSG in rat erythrocytes and tissues (Gultekin et al. 2001; Verma and Srivastava, 2003). Chlorpyrifos exposure causes inhibition of antioxidant enzyme activities and increase in the levels of hydrogen peroxide $\left(\mathrm{H}_{2} \mathrm{O}_{2}\right)$ in rat brain and liver (Gultekin et al. 2001; Verma and Srivastava 2003). Additionally, Chlorpyrifos was not mutagenic in the Ames Salmonella mutagenicity assay and mammalian cell cultures (CHO/HGPRT assay), cytogenetic abnormalities in mammalian cells both in vitro (rat lymphocyte chromosomal aberration test, RLCAT) and in vivo (mouse bone marrow micronucleus test) and induction of DNA damage and repair in rat hepatocytes in vitro (Gollapudi et al. 1995). Dursban 4 (Chlorpyrifos-ethyl) was decreased mitotic index and induced chromosome aberrations in the root meristem cells of Allium cepa (Topcu et al. 2013).

In the present study with Allium cepa root tip meristem cells, the three doses of Napoleon 4EC tested induced cytotoxicity thus corroborating the findings of these studies but not the in vitro studies with $S$. typhimurium cited above. There are some possible mechanisms for chemically decreased MI in plant cells. The significant decline in the mitotic index could be due to the inhibition of the DNA synthesis or the blocking of the G1 suppressing the DNA synthesis or effecting the test compound at the G2 phase of the cell cycle (Sudhakar et al. 2001; Majewska et al. 2003). When a pesticide penetrates the cells and reaches a critical dose, it could be an active form, causing lesions during several following cellular cycles (Marcano et al. 2004). The decrease of the mitotic index in our study can be related to this.

In this study, all the concentrations of Napoleon $4 \mathrm{EC}$ caused the changes in the percentage of the particular phases' distribution when compared to the control group. Pesticides accumulate in the cell due to this substance not being able to emerge out of the cell easily after once penetrating the cell and it may be highly toxic in the cell (Antunes-Madeira and Madeira 1979).

The safety evaluation of a fragrance material includes a broad range of toxicological information, both for the substance itself and for structurally related chemicals belonging to the same chemical group (Bickers et al. 2003). Among toxicological information, genotoxicity is a systemic consideration, as it can be related to carcinogenicity (Di Sotto et al. 2008). Normally, to evaluate a potential genotoxic risk due to a chemical exposition, in vitro assays for detecting point mutations (Ames test) and extended treatment (e.g., micronucleus assay, Allium test, single cell gel electrophoresis assay or comet assay) are used in the first instance (EMEA 2008; Di Sotto et al. 2013). If the results of these studies are positive, in vivo studies, for example a mammalian cytogenetic study, are performed (EFSA 2014).

In conclusion, Napoleon 4EC was determined to be cytotoxic due to reducing of MI in Allium test and weak mutagenic in Ames test. For this reason, further inves- 
tigations are needed to determine the toxicity of this compound using other in vivo and in vitro biological test systems. A single test system is not enough to determinate a compound whether it is toxic or non-toxic. In this study we performed two different test methods. However, for the reliable results, additional mutagenicity studies should be conducted. For example, the umu test may be used in conjunction with the Ames test, as it indicates carcinogens as those substances that induce the expression of the umu operon (Reifferschied and Heil 1996). The other in vivo or in vitro tests would help confirm the findings of the results and give predictions for the chemical's effect in an organism. Accordingly in order to healthy future generation, the unavoidable use and prescribed precautions be adhered to by the farmers being non target organism so as to minimize the possible health risks associated with the extensive use of pesticides.

\section{REFERENCES}

Aiub CA, Coelho EC, Sodré, E, Pinto, LF, Felzenszwalb I. 2002. Genotoxic evaluation of the organophosphorous pesticide Temephos. Genetics and Molecular Research. 301(2): 159-66.

Akyll D, and Konuk M. 2014. Detection of genotoxicity and mutagenicity of chlorthiophos using micronucleus, chromosome aberration, sister chromatid exchange, and Ames tests. Environmental Toxicology. 30(8): 937-45.

Akyıl D, Özkara A, Erdoğmuş SF, Eren Y, Konuk M, Sağlam E. 2015. Micronucleus assay in human lymphocytes after exposure to alloxydim sodium herbicide in vitro. Cytotechnology. 67(6): 1059-1066.

Aky1l D. 2019. Risk Assessment of Twister 5EC Insecticide by using Allium and Ames Test. Research Journal of Biotechnology. 14(7): 120-125.

Amer SM, Farah OR. 1974. Cytological effects of pesticides: Effect of the insecticide Roger on the mitosis of Vicia faba and Gossypium barbadense. Cytologia. 39: 507-514.

Antunes-Madeira MC, Madeira VMC. 1979. Interaction of insecticides with lipid membranes. Biochimica et Biophysica Acta. 550: 384-392.

Arriaga-Alba M, Ruiz-Perez NJ, Sanchez-Navarrete J, Angel BL, Flores-Lozada J, Blasco JL. 2013. Antimutagenic evaluation of vitamins B1, B6 and B12 in vitro and in vivo, with the Ames test. Food Chemical Toxicology. 53: 228-234.

Asita AO, Mokhobo MM. 2013. Clastogenic and cytotoxic effects of four pesticides used to control insect pests of stored products on root meristems of Allium cеpa. Environmental Natural Resources Research. $3(2)$.

Aufderheide M, Gressmann H. 2007. A modified Ames assay reveals the mutagenicity of native cigarette mainstream smoke and its gas vapour phase. Experimental and Toxicological Pathology. 58: 383-392.

Ballesteros E, Parrado MJ. 2004. Continuous solid-phase extraction and gas chromatographic determination of organophosphorus pesticides in natural and drinking waters. Journal of Chromatography A. 1029: 267273.

Bello-Ramı'rez AM, Carreo'n-Garabito BY, Nava-Ocampo AA. 2000. A theoretical oxidation of organophosphorus pesticides. Toxicology. 149: 63-68.

Bickers DR, Calow P, Greim HA, Hanifin JM, Rogers AE, Saurat JH, Sipes IG, Smith RL, Tagamii H. 2003. The safety assessment of fragrance materials. Regulation Toxicology and Pharmacology. 37: 218-273.

Bonciu E, Firbas P, Fontanetti CS, Wusheng J, Karaismailoğlu MC, Liud D, Menicucci F, Pesnya DS, Popescu A, Romanovsky AV, Schiff S, Ślusarczyk J, Souza CP, Srivastava A, Sutan A, Papini A. 2018. An evaluation for the standardization of the Allium cepa test as cytotoxicity and genotoxicity assay. 71 (3): 191-209.

Celik A, Mazmanci B, Camlica Y, Askin A, Çömelekoğlu U. 2003. Cytogenetic effects of lambda-cyhalothrin on Wistar rat bone marrow. Mutation Research. 539: 91-97.

Coral MN, Ucman S, Yıldız H, Oztas H, Dalkılıc S. 2009. Potential neoplastic effects of parathion-methyl on rat liver Journal of Environmental Sciences. 21: 696699.

Dean BJ, Brooks TM, Hodson-Walker G, Hutson DH. 1985. Genetic toxicology testing of 41 industrial chemicals. Mutation Research. 153: 57-77.

Di Sotto A, Evandri MG, Mazzanti G. 2008. Antimutagenic and mutagenic activities of some terpenes in the bacterial reverse mutation assay. Mutation Research. 653: 130-133.

Di Sotto A, Maffei F, Hrelia P, Castelli F, Sarpietro MG, Mazzanti G. 2013. Genotoxicity assessment of b-caryophyllene oxide. Regulation Toxicology and Pharmacology. 66: 264-268.

Ema M, Imamur T, Suzuki H, Kobayashi N, Naya M, Nakanishi J. 2012. Evaluation of genotoxicity of multi-walled carbon nanotubes in a battery of in vitro and in vivo assays. Regulatory Toxicology and Pharmacology. 63: 188-195.

EMEA, 2008. Committee on Herbal Medicinal Products (HMPC), Guideline on the Assessment of Geno- 
toxicity of Herbal Substances/Preparations. EMEA/ HMPC/ 107079/2007.

Enan MR. 2009. Genotoxicity of the herbicide 2, 4-dichlorophenoxyacetic acid (2,4-D): higher plants as monitoring systems. American-Eurasian Journal of Sustainable Agriculture. 3: 452-459.

Escobar PA, Kemper RA, Tarca J, Nicolette J, Kenyon M, Glowienke S, Sawant SG, Christensen J, Johnson TE, McKnight C, Ward G, Galloway SM, Custer L, Gocke $\mathrm{E}$,

European Food Safety Authority CEF Panel (EFSA Panel on Food Contact Materials, Enzymes, Flavourings and Processing Aids). 2014. Scientific opinion on flavouring group evaluation 213 , revision 1 (FGE.213Rev1): consideration of genotoxic potential for a,b-unsaturated alicyclic ketones and precursors from chemical subgroup 2.7 of FGE.19. EFSA J. 12: 3661-3707

Fernandes TCC, Mazzeo DEC, Marin-Morales MA. 2007. Mechanism of micronuclei formation in Marcano L, Carruyo I, Del Campo A, Montiel X (2004) Cytotoxicity and mode of action of maleic hydrazide in root tips of Allium cepa L. Environmental Research. 94: 221-226.

Fiskesjo G. 1985. The Allium test as standard in environmental monitoring. Hereditas. 102: 99-112.

Gollapudi BB, Mendrala AL, Linscombe VA. 1995. Evaluation of the genetic toxicity of the organophosphate insecticide chlorpyrifos. Mutation Research. 342: 25-36.

Gómez-Arroyo S, Sánchez-Estrada L, Andrade-Morales S, Cortés-Eslava J, Villalobos-Pietrini R. 2015. Genotoxic effect of Azinphos methyl in bacteria and in human lymphocyte cultures after plant activation. Revista Internacional de Contaminacion Ambiental. 31(3): 227-236.

Gultekin F, Delibas N, Yasar S, Kilinc I. 2001. In vivo changes in antioxidant systems and protective role of melatonin and a combination of vitamin $\mathrm{C}$ and vitamin $\mathrm{E}$ on oxidative damage in erythrocytes induced by chlorpyrifos-ethyl in rats. Archives of Toxicology. 75: 88-96.

Karaismailoglu MC. 2016. The evaluation of the genotoxic and cytotoxic effects of Pyriproxyfen insecticide on Allium cepa somatic chromosomes with mitotic activity, chromosome abnormality and micronucleus frequency. Turkish Journal of Life Sciences.1(2): 65-69.

Kaur M, Arora S, Nagpal A, Katnoria JK. 2014. Clastogenic effects of synthetic food dyes using Salmonella typhymurium and Allium cepa test systems. Indian Journal of Biotechnology. 13: 547-550.
Khallef M, Cenkci S, Akyıl D, Özkara A, Konuk M, Benouareth D. 2017. Ames and random amplified polymorphic DNA tests for the validation of the mutagenic and/or genotoxic potential of the drinking water disinfection by-products chloroform and bromoform. Journal of Environmental Science Health Part A. 1-6.

Konuk M, Liman R, Cigerci IH. 2007. Determination of genotoxic effect of boron on Allium cepa root meristematic cells. Pakistan Journal of Botany. 39: 73-79.

Kumar A, Sharma K, Tomar M, Malik V, Kataria SK. 2013. Determination of mutagenic potential of Imidacloprid in Salmonella typhimurium-TA 98 and TA 100 following bacterial reverse mutation assay. International Journal of Biotechnology and Bioengineering Research. 4(7): 703-710.

Kutlu M, Öztaş E, Aydoğan G, Işıkdağ İ, Özkay Y. 2011. An investigation of mutagenic activities of some 9- substitued phenanthrene derivatives with Ames/Salmonella / Microsome test. Anadolu University Journal of Science Technology-C. Life Science Biotechnology. 1: 83-94.

Liman R, Akyıl D, Eren Y, Konuk M. 2010. Testing of the mutagenicity and genotoxicity of metolcarb by using both Ames/Salmonella and Allium test. Chemosphere. 80: 1056-1061.

Linnainmaa K, Meretoja T, Sorsa M, Vainio H. 1978. Cytogenetic effects of styrene and styrene oxide, Mutat Res. 58(2-3): 277-286.

Majewska AE, Wolska E, Sliwinska M, Furmanowa N, Urbanska A, Pietrosiuk A, Zobel A, Kuran M. 2003. Antimitotic effect, G2/M accumulation, chromosomal and ultrastructure changes in meristematic cells of Allium cepa L. root tips treated with the extract from Rhadiola rosea roots. Caryologia. 56: 337-351.

Malev O. 2012. Toxic effects of selected neonicotinoids through different organisational levels: in vitro and in vivo studies. University of Nova Gorica, Graduate School.

Maron DM, Ames BN. 1983. Revised methods for the mutagenicity test. Mutation Research. 113: 173-215.

Mehta A, Verma RS, Srivastava N. 2008. Chlorpyrifosinduced DNA damage in rat liver and brain. Environmental Molecular Mutagenesis. 49: 426-433.

Miao J, Wang D, Yan J, Wang Y, Teng M, Zhou Z, Zhu W. 2017. Comparison of subacute effects of two types of pyrethroid insecticides using metabolomics methods.

Pesticides Biochemical Physiology. 143: 161-167.

Mortelmans K, Zeiger E. 2000. The Ames Salmonella/ microsome mutagenicity assay. Mutation Research. 445: 29-60.

Moulas C, Petsoulas C, Rousidou K, Perruchon C, Karas P, Dimitrios GK. 2013. Effects of systemic pesticides 
Imidacloprid and Metalaxyl on the phyllosphere of pepper plants. BioMed Research International. 8 .

Obare SO, De C, Guo W, Haywood TL, Samuels TA, Adams CP, Masika NO, Murray DH, Anderson GA, Campbell K, Fletcher K. 2010. Fluorescent chemosensors for toxic organophosphorus pesticides: a review. Sensors. 10: 7018-7043.

O'Donovan MR, Braun K, Snyder RD, Mahadevan B. 2013. Bacterial mutagenicity screening in the pharmaceutical industry. Mutation Research. 752: 99-118.

Özkara A, Akyıl D, Eren Y, Erdogmus SF. 2015. Potential cytotoxic effect of Anilofos by using Allium cepa assay. Cytotechnology. 67: 783-791.

Özkara A, Akyll D, Eren Y, Erdogmus SF. 2015b. Potential cytotoxic effect of Anilofos by using Allium cepa assay. Cytotechnology. 67(5): 783-791.

Özkara A, Akyıl D, Eren Y, Erdogmus SF, Konuk M, Saglam E. 2015a. Assessment of cytotoxic and genotoxic potential of pyracarbolid by Allium test and micronucleus assay. Drug and Chemical Toxicology. 38(3): 337-341.

Özkara A. 2017. Evaluation of Siperkor pesticide mutagenicity with Ames test. Afyon Kocatepe University Journal of Sciences and Engineering. 17(2): 393-398.

Özkara A. 2019. Assessment of cytotoxicity and mutagenicity of insecticide Demond EC25 in Allium cepa and Ames Test. Caryologia. 72(2): 21-27.

Panda BB, Sahu UK. 1985. Induction of abnormal spindle function and cytokinesis inhibition in mitotic cells of Allium cepa by the organophosphorus insecticide Fensulfothion. Cytobios. 42: 147-155.

Paolini M, Forti GC. 1997. On the metabolizing systems for shortterm genotoxicity assays: A review. Mutation Research. 387: 17-34.

Reifferscheid G, Heil J. 1996. Validation of the SOS/umu test using test results of 486 chemicals and comparison with the Ames test and carcinogenicity data. Mutation Research/Genetic Toxicolology. 369: 129-145.

Santosh K, Srivastava YN, Marotta F, Jain S, Yadav H. 2012. Evaluation of micronuclei induction capacity and mutagenicity of organochlorine and organophosphate pesticides. Drug Metabolism Letters. 6 .

Siddiqui S, Al-Rumman S. 2020. Clethodim induced pollen sterility and meiotic abnormalities in vegetable crop Pisum sativum L. Caryologia 73(1): 37-44.

Siroki O, Undeger U, Institoris L, Nehez M, Basaran N, Nagymajtényi L, Dési I. 2001. A study on genoand immunotoxicological effects of subacute propoxur and pirimicarb exposure in rats. Ecotoxicol Environmental Safety. 50: 76-81.

Stivaktakis P, Vlastos D, Giannakopoulos E, Demetrios PM. 2010. Differential micronuclei induction in human lymphocyte cultures by imidacloprid in the presence of potassium nitrate. Research Article in the Science World Journal. 10: 80-89.

Sudhakar R, Gowda N, Venu G. 2001. Mitotic abnormalities induced by silk dyeing industry effluents in the cells of Allium cepa. Cytologia. 66: 235-239.

Topcu S, Yllmaz F, Ergene A, Tan S. 2013. Genotoxic effects of Dursban 4 in Allium cepa. Hacettepe Journal of Biology and Chemistry. 41(1): 21-27.

Verma RS, Srivastava N. 2003. Effect of chlorpyrifos on thiobarbituric acid reactive substances, scavenging enzymes and glutathione in rat tissues. Indian Journal of Biochemistry and Biophysics. 40: 423-428.

Yaduvanshi NPS, Setter TL, Sharma SK, Singh KN, Kulshreshtha N. 2012. Influence of waterlogging on yield of wheat (Triticum aestivum), redox potentials, and concentrations of microelements in different soils in India and Australia, Soil Research. 50: 489499.

Wu J, Lin L, Luan T, Gilbert YSC, Lan C. 2007. Effects of organophosphorus pesticides and their ozonation by products on gap junctional intercellular communication in rat liver cell line. Food and Chemical Toxicology. 45: 2057-2063.

Wu JC, Chye SM, Shih MK, Chen CH, Yang HL, Chen SC. 2012. Genotoxicity of Dicrotophos, an organophosphorus pesticide, assessed with different assays in vitro. Environmental Toxicology. 27: 307-315.

Ylldız M, Cigerci IH, Konuk M, Fidan AF, Terzi H. 2009. Determination of genotoxic effects of copper sulphate and cobalt chloride in Allium cepa root cells by chromosome aberration and comet assays. Chemosphere. 75: 934-938. 